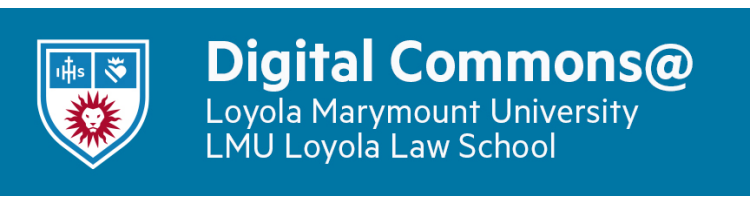

Journal of Catholic Education

$12-1-2006$

\title{
A Model School: How Philadelphia's Gesu School is Remaking Inner-City Education, by Jerrold K. Footlick
}

Sharon Zogby

Follow this and additional works at: https://digitalcommons.Imu.edu/ce

\section{Recommended Citation}

Zogby, S. (2006). A Model School: How Philadelphia's Gesu School is Remaking Inner-City Education, by Jerrold K. Footlick. Journal of Catholic Education, 10 (2). http://dx.doi.org/10.15365/joce.1002092013

This Book Review is brought to you for free with open access by the School of Education at Digital Commons at Loyola Marymount University and Loyola Law School. It has been accepted for publication in Journal of Catholic Education by the journal's editorial board and has been published on the web by an authorized administrator of Digital Commons at Loyola Marymount University and Loyola Law School. For more information about Digital Commons, please contact digitalcommons@lmu.edu. To contact the editorial board of Journal of Catholic Education, please email JCE@nd.edu. 


\title{
BOOK REVIEWS
}

\section{A MODEL SCHOOL: HOW PHILADELPHIA'S GESU SCHOOL IS REMAKING INNER-CITY EDUCATION}

\author{
JERROLD K. FOOTLICK \\ VILLIGER PRESS, 2004 \\ $\$ 20.00,227$ pages
}

Reviewed by Sharon Zogby

In the realm of educational literature, seldom does an educator find a book which is difficult to put down. In A Model School: How Philadelphia's Gesu School is Remaking Inner-City Education, Footlick inspires and excites, giving the reader a glimpse of a true Catholic educational community in action. This book tells the story of how several dedicated people in one of North Philadelphia's worst neighborhoods resurrected Gesu School after the Church of the Gesu was closed in 1993 by Philadelphia's Cardinal Bevilacqua. Even though he was closing the church building, the Cardinal asked the Jesuits and the Sisters, Servants of the Immaculate Heart of Mary, to continue to keep the school open as a private Catholic school. This independent school is not part of the Archdiocese of Philadelphia, but does purchase textbooks through the Archdiocesan Education Office and also receives federally funded lunches through them.

Under the guidance of Reverend George Bur, S.J., and Sister Ellen Convey, I.H.M., and many dedicated staff members, Gesu School currently serves over 400 African American children in pre-kindergarten through eighth grade. Half of the children come from families with no church membership. Of the other half, most are Baptist, and about one in six is Catholic, though not necessarily active in the Church. Like every school, Gesu has problems, but in an area which has a $60-70 \%$ high school dropout rate, Gesu is providing children with the skills to successfully complete high school and beyond. Many of these graduates go on to become their families' first generation of teachers, professionals, and office workers. How does Gesu do it?

For teachers, our primary question is centered upon the curriculum used by a successful school. As in any school, Gesu's curriculum is important and its teachers instruct with passion and high expectations for success. Gesu has excellent teachers and a support staff which includes full-time art and phys-

Catholic Education: A Journal of Inquiry and Practice, Vol. 10, No. 2, December 2006, 248-263 (C) 2006 University of Notre Dame. 
ical education teachers, a full-time librarian, computer teacher, and counselor, as well as a part-time writing teacher. The success of Gesu School, however, is more than curriculum and its delivery.

Chapters 5 and 6 of Footlick's book highlight two innovations which may be of interest to administrators and teachers alike. One is the single-sex program used at Gesu. Initiated originally to sustain male enrollment past the elementary grades, Grades 3, 4, and 5 feature single-sex classes in which the teacher is a strong male who acts as a role model for the boys. It is believed that separating the boys from the girls at this age fosters more appropriate behavior as well as stronger academic performance.

A second innovation which sets Gesu's students apart is a writing program which began in 1999 when Sister Ellen found that her brightest students were not being accepted to prestigious high schools due to weak writing skills. Hiring a writing teacher was the answer, and students receive direct instruction in various forms of writing. Writing and language arts teachers may particularly enjoy and celebrate the samples of student writing which are featured in chapter 6 .

For many inner-city children, school is more than just a place where they learn; it provides security and a sense of normalcy. Often children come from a home in which there is drug or alcohol abuse; many are being raised by grandparents. Throughout this book, one cannot help but be inspired by the leadership and tremendous contribution of Gesu's principal, Sister Ellen Convey, I.H.M. There appears to be no stone unturned in Sister Ellen's repertoire of caring for her children. Gesu welcomes many visitors to its school and one such visitor is Gail Avicolli, former regional director for the Philadelphia Office of Catholic Education. Footlick states that the enthusiasm of the principal and her staff impresses visitors immediately and quotes Avicolli on the spirit found at Gesu:

It's very clear that this is a school that is going to treat you like family.... The opportunities are here-all the pieces are in place, support for individual academic differences, the textbooks, the paper, the cleanliness, the health services, the counseling, the follow through. Sister [Ellen] has a washing machine here and children's things are washed if they're not clean. There isn't one part of the social, emotional, religious, or academic needs that is not addressed. (p. 51)

Even though only one in six of Gesu's students are of the Catholic faith, strong Catholic values are present in the philosophy of Father Bur and the sisters. Father Bur is quoted as saying: "The sisters carry out the community's mission statement by challenging attitudes, lifestyles, and values which are in conflict with the word of God. They share their ministry in humility, friendship and love" (p. 77). And they continue "to invite all they meet into 
the full sacramental life of the Church" (p. 77). As the percentage of nonCatholic students grows in urban Catholic schools, it is interesting to read of the religious and sacramental instruction which is an integral part of life at Gesu.

Another uplifting part of Gesu's story is the amazing amount of philanthropy which has been spearheaded by a Philadelphia executive named Winston Churchill (no relation to the British Winston Churchill), who is a former classmate of Father Bur. The book tells of many generous donations of time as well as talent which have benefited the school. These benefactors have solicited million dollar contributions in order to set up an endowment fund which will generate income for future operations. Readers will also be interested to learn that the board members of Gesu School belong to many faiths and ethnicities.

Whether one is a teacher, principal, administrator, pastor, or student, this reviewer recommends this book as an insight into standards to which any school, but particularly an inner-city school, can aspire. The book, which also includes a photo journal, will truly inspire and uplift every reader. As the author states: "So yes, it's religion, but only partly, and social values, but only partly, and community needs, but only partly. It's mostly about the children, the children of God" (p. 81).

Sharon Zogby is a reading specialist and the assistant principal at Holy Family Parish School in Peoria, IL.

\section{REIMAGINING THE CATHOLIC SCHOOL}

NED PRENDERGAST \& LUKE MONAHAN, EDS.

VERITAS, 2003

$\$ 25.00,290$ pages

Reviewed by Christopher MacGuire

In March 2001, the Marino Institute of Education, established by the Irish Christian Brothers, spearheaded a project to bring a diverse group of Church leaders and professionals together to discuss many of the Catholic Church's pending issues. There was great representation by dioceses, schools, and parishes. These parish advisors, school administrators, religious education 